PNL-7348

UC-603

$6 A$

\title{
Honeybees as Monitors of Low Levels of Radioactivity
}

M. A. Simmons

J. J. Bromenshenk

J. L. Gudatis

July1990

Prepared for the U.S. Department of Energy under Contract DE-AC06-76RLO 1830

Pacific Northwest Laboratory

Operated for the U.S. Department of Energy

by Battelle Memorial Institute 


\title{
DISCLAIMER
}

This report was prepared as an account of work sponsored by an agency of the United States Government. Neither the United States Government nor any agency thereof, nor Battelle Memorial Institute, nor any of their employees, makes any warranty, expressed or implied, or assumes any legal liability or responsibility for the accuracy, completeness, or usefulness of any information, apparatus, product, or process disclosed, or represents that its use would not infringe privately owned rights. Reference herein to any specific commercial product, process, or service by trade name, trademark, manufacturer, or otherwise, does not necessarily constitute or imply its endorsement, recommendation, or favoring by the United States Government or any agency thereof, or Battelle Memorial Institute. The views and opinions of authors expressed herein do not necessarily state or reflect those of the United States Government or any agency thereof.

\author{
PACIFIC NORTHWEST LABORATORY \\ operated by \\ BATTELLE MEMORIAL INSTITUTE \\ for the \\ UNITED STATES DEPARTMENT OF ENERGY \\ under Contract DE-ACO6-76RLO 1830
}

Printed in the United States of America

Available to DOE and DOE contractors from the

Office of Scientific and Technical Information, P.O. Box 62, Oak Ridge, TN 37831; prices available from (615) 576-8401. FTS 626-8401.

Available to the public from the National Technical Information Senvice, U.S. Department of Commerœ, 5285 Pon Royal Rd, Springficld. VA 22161.

NTIS Price Codes, Microfiche A01

Printed Copy

\begin{tabular}{ccccc}
\hline Price Code & Page Range & & Price Code & Page Range \\
\cline { 5 - 5 } \cline { 4 - 5 } A02 & $1-10$ & & A15 & $326-350$ \\
A03 & $11-50$ & & A16 & $351-375$ \\
A04 & $51-75$ & & A17 & $376-400$ \\
A05 & $76-100$ & & A18 & $401-425$ \\
A06 & $101-125$ & & A19 & $426-450$ \\
A07 & $126-150$ & & A20 & $451-475$ \\
A08 & $151-175$ & & A21 & $476-500$ \\
A09 & $176-200$ & & A22 & $501-525$ \\
A10 & $201-225$ & & A23 & $526-550$ \\
A11 & $226-250$ & & A24 & $551-575$ \\
A12 & $251-275$ & & A25 & $576-600$ \\
A13 & $276-300$ & A99 & $601-4 p$ \\
A14 & $301-325$ & &
\end{tabular}




\title{
33679000550915
}

PNL-7348

UC -603

HONEYBEES AS MONTTORS OF LON LEVELS OF RADIOACTIVITY

\author{
M. A. Simmons \\ J. J. Bromenshenk (a) \\ J. L. Gudatis(a)
}

July 1990

Prepared for the U.S. Department of Energy under Contract DE-AC06-76RLO 1830

Pacific Northwest Laboratory Richland, Washington 99352

(a) Zoology Department University of Montana Missoula, Montana 59812 



\section{$\underline{\text { SUMMARY }}$}

Large-scale environmental monitoring programs rely on sampling 'many media--air, water, food, et cetera--from a large network of sampling stations. Although these programs are extensive, it is not possible to cover the entire region. For describing the total region possibly impacted by contaminants, the most efficient samplerwould be one that covered a large region and simultaneously sampled many different media, such as water, air, soil, and vegetation. Honeybees have been shown to be useful monitors of the environment in this context for detecting both radionuclides and heavy metals.

This study sought to determine the effectiveness of honeybees as monitors of low levels of radioactivity in the form of tritium and gammaemitting radionuclides. For the study, approximately 50 honeybee colonies were placed on the Hanford Site and along the Columbia River in areas downwind of the site. The mini-hive colonies were sampled after 1 month and tested for tritium and for gamma-emitting radionuclides. Tritium concentrations for all but two sites were below detection limits. The two significant concentrations of 1 and $2 \mathrm{pCi} / \mathrm{mL}$ were detected at sites along the Columbia River across from the Hanford Site. All gamma-emitting radionuclide concentrations in honeybees were below detection limits except for cesium-137 found near Gable Mountain Pond on the Hanford Site. The $0.4 \pm 0.08 \mathrm{pCi} / \mathrm{g}$ (dry weight) cesium-137 concentration was similar to that monitored in vegetation from the same site.

From this and other studies, it is known that honeybees can be used to detect radionuclides present in the environment. Their mobility and their ability to integrate all exposure pathways (i.e., water, air, vegetation, and soil) could expand and add another level of confidence to the present monitoring program. 



\section{ACNOWEDGENTS}

For this study, L. J. Kirby and E. A. Lepel did the radionuclide analyses, L. A Athey and M. E. Thiede provided field assistance, S. Trevathan assisted in selecting sample sites, R. Cronin reviewed early drafts of this manuscript, and J. M. Thomas oversaw the design and implementation of the study. This work was supported by the U.S. Department of Energy, Ecological Research Division, and the U.S. Environmental Protection Agency. Although this research was funded in part by the U.S. Environmental Protection Agency, it has not been subjected to Agency review and therefore does not necessarily reflect the views of the Agency, and no official endorsement should be inferred. 



\section{CONTENTS}

SUMMARY . . . . . . . . . . . . . . . . . . . . . . ACKNOWLEDGMENTS .................... . . . . . .

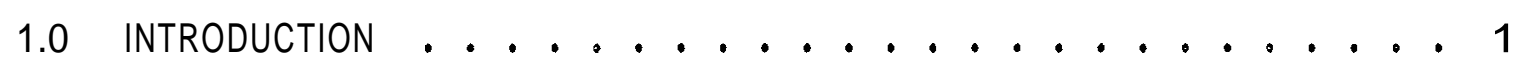

2.0 MATERIALS AND METHODS . . . . . . . . . . . . . . . 3

. 3.0 RESULTS AND DISCUSSION .................. 5

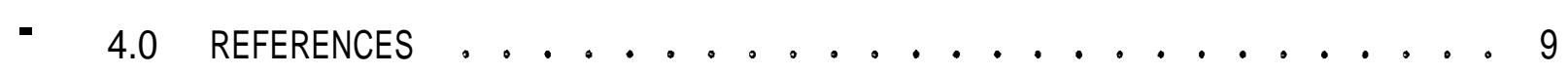





\subsection{INTRODUCTION}

Environmental monitoring generally involves sampling specific media such as air, water, or soil at a fixed location. This type of monitoring works best for contaminants that are contained or that follow a known dispersive pattern such as the drainage system of a waste site. In many cases, however, the means of contamination is not known and the spread is over a large area and/or is dependent on variable weather conditions. For example, wind conditions at the time of the release is one process affecting the dispersal of a plume of contaminated air. To describe the area impacted by such a plume, a sampler is needed that either covers, or can move over, a large area. But to be economically feasible, the samples could only be collected in a few locations. One solution would be a mobile sampler that covers a relatively large area and then returns to a fixed location. Bees fit this description and are useful monitors of the environment. Honeybees (Apis mellifera) forage over fairly large areas (up to $7 \mathrm{~km}^{2}$ in well-fed situations (Bromenshenk et al. 1985) and up to $100 \mathrm{~km}^{2}$ under natural foraging situations (Visscher and Seeley 1982). They also sample all three media through which pollutants are transported (i.e., gases, liquids, and particulates). Because honeybees return to a fixed location (i.e., the hive) sampling activity can be concentrated, as with a fixed sampler. Honeybees can be deployed in any area where there is sufficient food. This requirement limits the usefulness of bees as an environmental monitor to the growing season. However, because honeybees are kept both by private hobbyists and commercial beekeepers, one area can contain a large number of potential sampling sites (Bromenshenk et al. 1985).

Honeybees have been used to determine the distribution of heavy metals, such as arsenic and fluoride (Bromenshenk et al. 1985), and of radionuclides (Kirkham and Corey 1977; Hakonson and Bostick 1976). For heavy-metal detection (Bromenshenk et al. 1985), private beekeepers in an urban setting provided much of the data.

The Hanford Site and its surrounding areas are monitored by an extensive but static network of air, water, soil, and vegetation samplers (Price 1985). Radioactivity ranges from detectable levels at some onsite areas to levels 
that approach background radioactivity across the Columbia River from the Hanford Site (Price 1985). To test the effectiveness of honeybees as monitors of low levels of radioactivity, beehives were placed on the Hanford Site and along a 40-mile stretch of the Columbia River. 


\subsection{MATERIALS AND METHODS}

Approximately 50 mini-hives were deployed along the Columbia River, from the city of Pasco, Washington, to a point approximately 40 miles to the north. Mini-hives were also placed at several potentially contaminated sites on the Hanford Site (Figure 1). Mini-hives, which are approximately onethird the size and cost of regular hives, were used because they are easy to move and set up. Honeybees, from Hermiston, Oregon, were placed in minihives supplied by the University of Montana and were moved to an area south of the Hanford complex, where they remained for 2 months before being placed at test sites. Twenty-one test sites were selected; five coincided with airsamplers used in the Hanford Environmental Monitoring Program (Price 1985) and four were at sites with commercial hives. Thirteen hives were placed on the Hanford Site at five locations. Two of the onsite locations coincided with air samplers, and two were near waste ponds. The mini-hives remained in these locations for approximately 1 month. After sampling, the remaining bees and hives were shipped to the University of Montana.

Two samples were taken for radioanalysis. One sample, for a general survey of gamma-emitting radionuclides, was taken at the site. Several hundred honeybees were aspirated into a polyethylene sample bag using a PVC and acrylic aspirator attached to a 12-volt vacuum and were placed on ice until they could be frozen. The frozen bees were shipped to the University of Montana, where they were dried in a forced-air oven at 45'C. Samples were returned to the Pacific Northwest Laboratory (PNL) where they were counted for 24 hours using a Lithium-Drifted Germanium [Ge(Li)] detector with a multi-channel pulse-height analyzer. This method is used to analyze water, soil, vegetation, and wildlife for the Hanford Environmental Monitoring Program (Price 1985) and provides a general indication of the degree of radionuclide contamination.

The second sample, for tritium analysis, was collected when the minihives were disassembled in Montana. After the bees were collected, they were microwaved and the liquid was collected. The liquid samples were returned to PNL, where tritium concentrations were determined on 4-mL aliquots by liquid scintillation spectrometry (U.S. Dept. HEW 1967). 

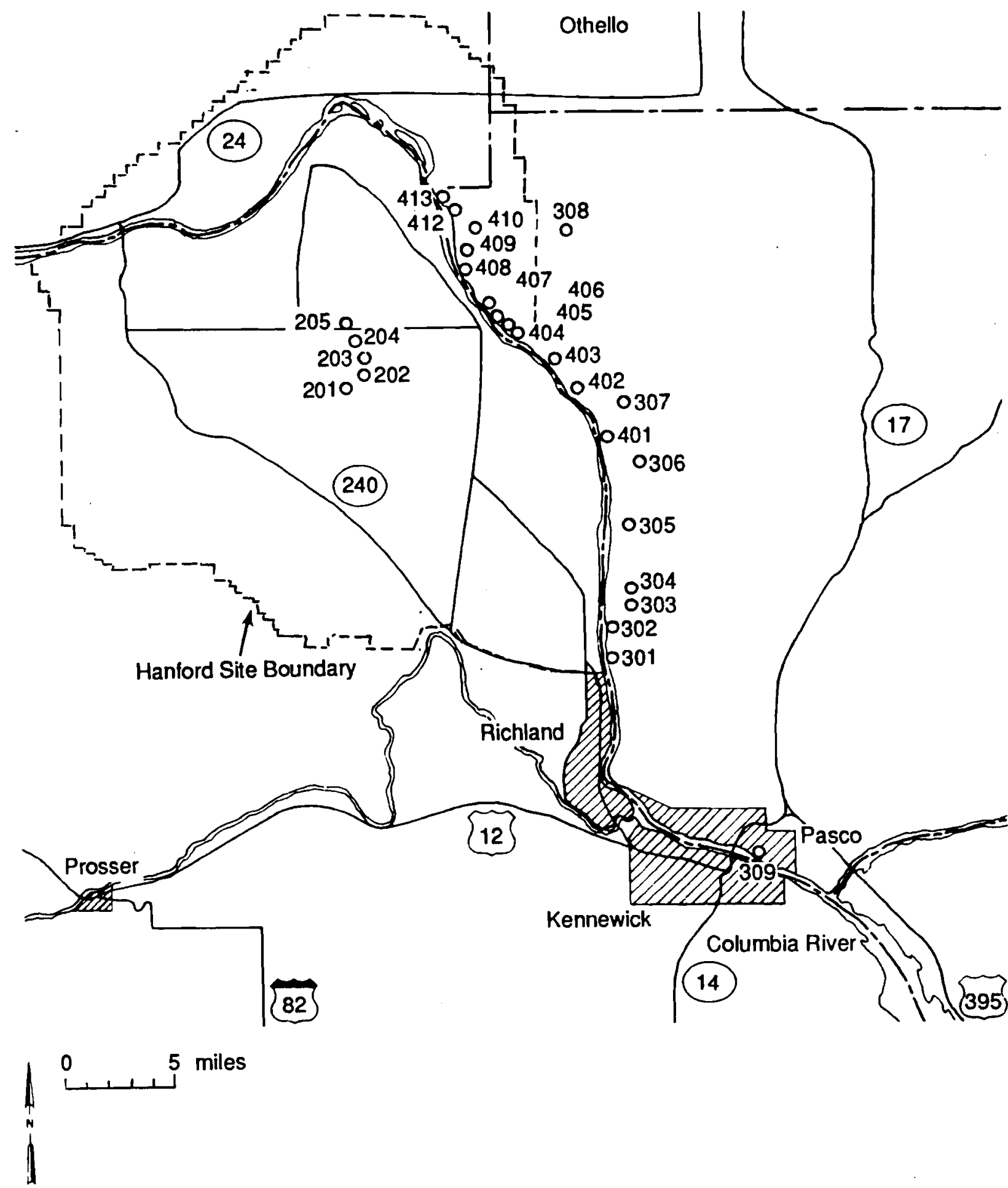

FIGURE 1. Location of Mini-Hive Colonies on the Hanford Site and Along the East Side of the Columbia River 


\subsection{RESULTS AND DISCUSSION}

In general, tritium concentrations were below detection limits (Table 1). Concentrations within 2 sd (standard deviations) are considered to be within counting error and are not significantly different from zero. Only two honeybee samples (Hives 18 and 54, Table 1) contained tritium concentrations greater than $2 \mathrm{sd}$; the concentrations were slightly over 1 $\mathrm{pCi} / \mathrm{mL}$ and $2 \mathrm{pCi} / \mathrm{mL}$, respectively. These samples were from sites 306 and 404 (Figure 1). A study of tritium concentrations in honeybees from contaminated sites at Los Alamos (Hakonson and Bostick 1976) indicated several sources for the tritium. During the growing season, concentrations in the honeybees were similar to those in vegetation, while at other times, honeybee tritium concentrations were similar to surface-water levels. In the vegetation, there were two sources of tritium: contaminated soil and atmospheric releases. Sources of tritium at Savannah River (Kirkham and Corey 1977) appeared to be atmospheric releases, with tritium concentrations in honeybees ranging from $8 \mathrm{pCi} / \mathrm{mL}$ at a control site to nearly $400 \mathrm{pCi} / \mathrm{mL}$ at a contaminated site. While there are several possible sources of the tritium at sites 306 and 404, data are only available for the Columbia River. Tritium concentrations in Columbia River water samples for 1985 averaged 0.15 $\mathrm{pCi} / \mathrm{mL}$, with a maximum of $0.22 \mathrm{pCi} / \mathrm{mL}$ (Price 1985, Tables A.13, A.14). No data are reported for tritium concentration in vegetation.

On the Hanford Site, tritium concentrations in honeybees agreed well with concentrations in ponds. At B Pond (Price 1985, Table A.15), tritium concentrations ranged from 0.2 to $1.1 \mathrm{pCi} / \mathrm{mL}$, while in honeybees, concentrations ranged from 0.01 to $0.46 \mathrm{pCi} / \mathrm{mL}$; at Gable Mountain Pond, tritium concentrations ranged from 0.07 to $0.40 \mathrm{pCi} / \mathrm{mL}$, while honeybee concentrations were 0.0 to $0.25 \mathrm{pCi} / \mathrm{mL}$.

All gamma-emitting radionuclide concentrations in honeybees were below detection limits except for cesium-137 at one site. Honeybees from one of the hives at Gable Mountain Pond (site 205) on the Hanford Site (Figure 1) contained approximately $0.4 \pm 0.08 \mathrm{pCi} / \mathrm{g}$ (dry weight) of cesium-137 (approximately $0.13 \mathrm{pCi} / \mathrm{g}$, wet weight). A comparison of this cesium-137 concentration with concentrations in air, soil, water (i.e., Gable Mountain 
Table 1. Tritium Concentrations $(\mathrm{pCi} / \mathrm{mL}$ ) for Honeybees from Mini-Hives Placed on the Hanford Site and Along the East Bank of the Colombia River. See Figure 1 for Hive Locations

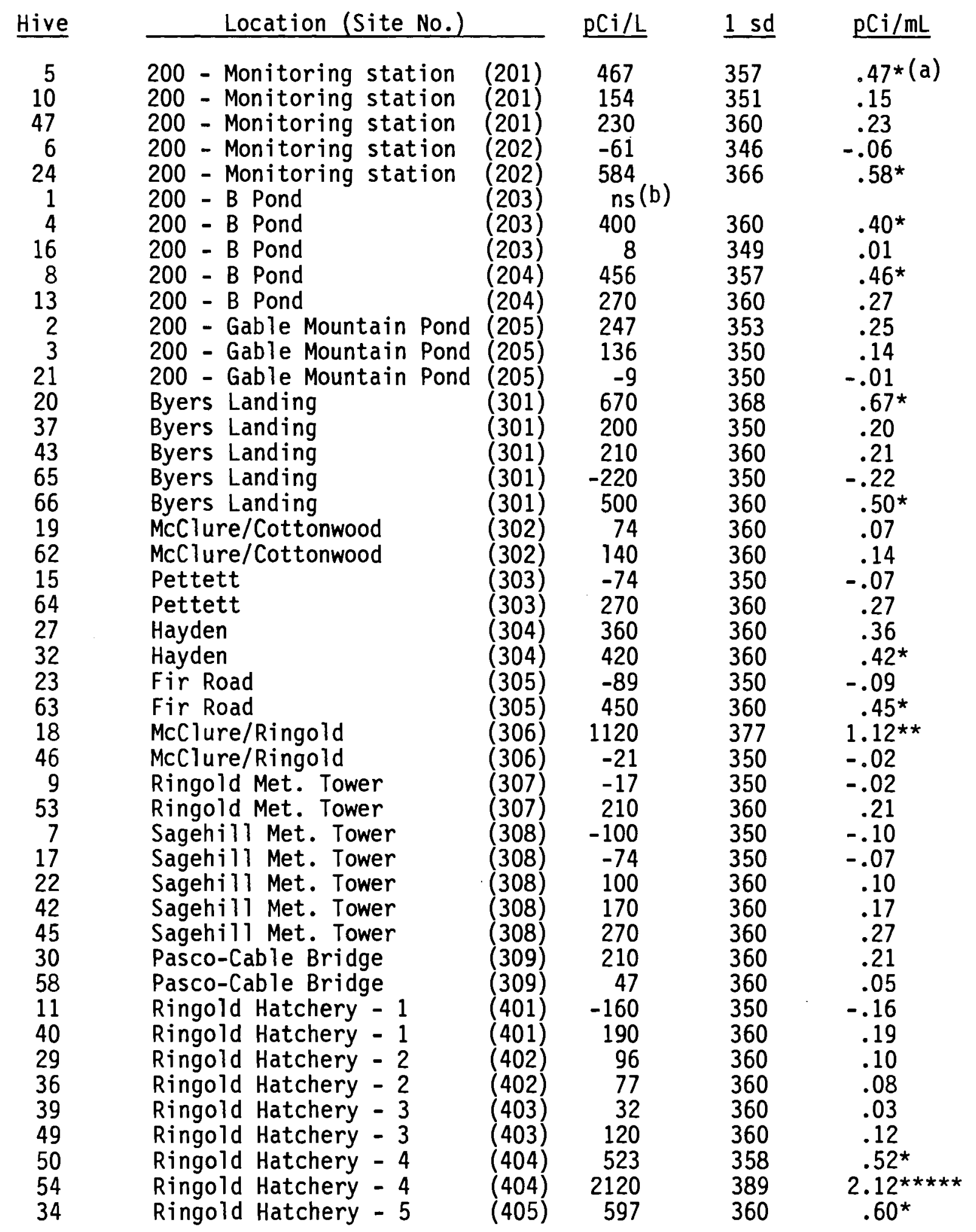


Table 1. (continued)

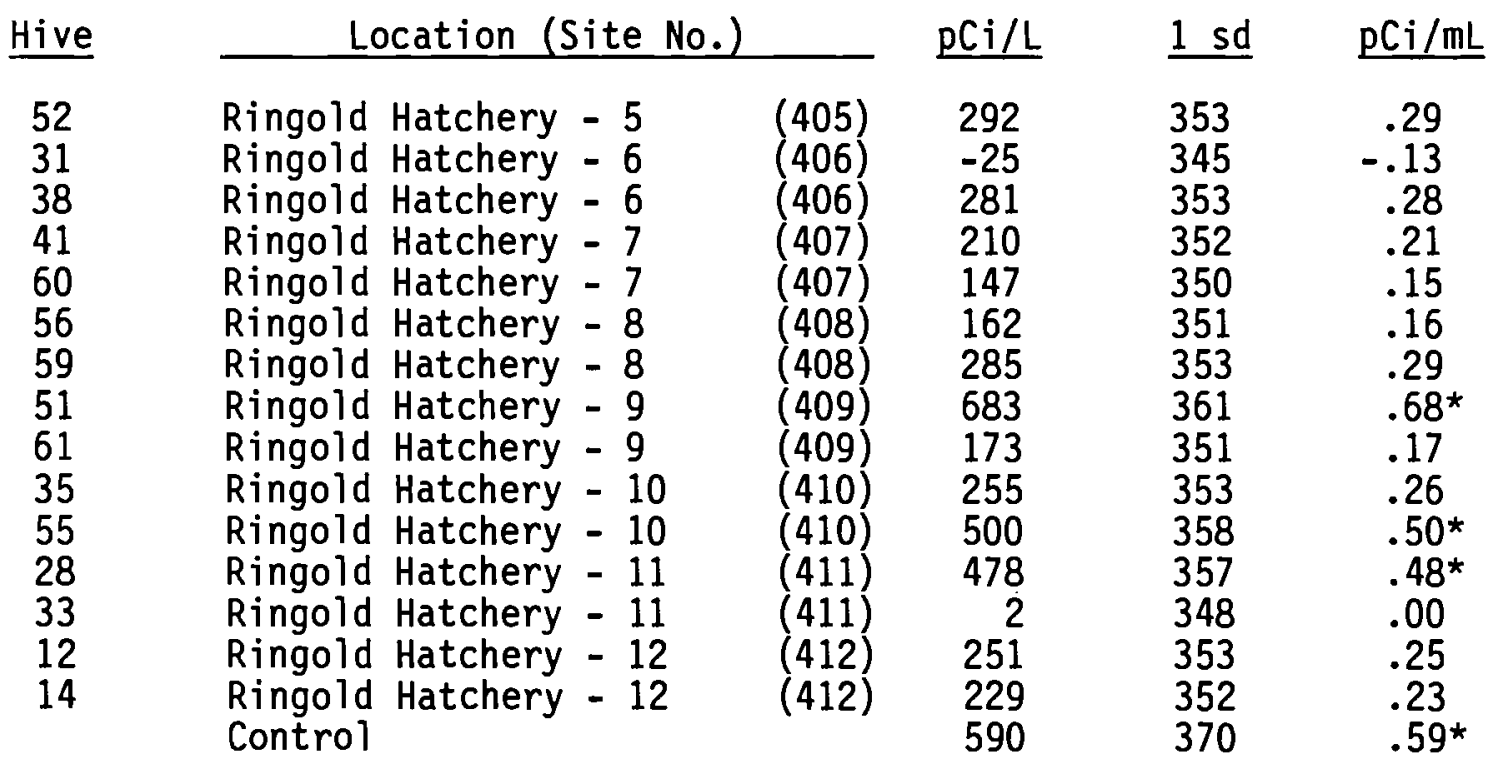
(a) $*$ greater than number of standard deviations (e.g., * $=1 \mathrm{sd}, * *=2 \mathrm{sd}$ )
(b) $\mathrm{ns}=$ no sample

Pond), animal, and vegetation samples at the Hanford Site (Table 2) shows that the concentration in honeybees was similar to that in vegetation samples (Price 1985).

Cesium concentrations in honeybees at contaminated sites at Los Alamos (Hakonson and Bostick 1976) ranged from 0.1 to $1 \mathrm{pCi} / \mathrm{g}$ (dry weight) and corresponded to levels in a contaminated stream. At Savannah River (Kirkham and Corey 1977), control honeybees had a concentration of $0.4 \mathrm{pCi} / \mathrm{g}$ while concentrations in honeybees from contaminated sites ranged from 0.99 to 8.3 $\mathrm{pCi} / \mathrm{g}$. Vegetation appeared to be the primary source of cesium-137 at Savannah River.

Honeybees can be used to monitor radioactivity. Where contamination exists, the concentration in honeybees reflects levels found in vegetation, air, and water. The bees integrate all exposure pathways and provide a summation of the environmental burden. Thus, sampling of honeybee colonies would add another level of confidence to the monitoring programs carried out for areas downwind from the Hanford Site. Incorporating a honeybee sampling 
Table 2. Cesium-137 Concentrations in Various Media on the Hanford Site (Price 1985).

\begin{tabular}{l} 
Media \\
\hline Air (200 East Area) \\
Gable Mountain Pond \\
Deer \\
Gamebirds \\
Ducks \\
Rabbits \\
Soil \\
Vegetation
\end{tabular}

Concentration (a)

$\begin{array}{lll}0.0012 & \pm 0.0007 \\ 17.0 & \pm & 2.6 \\ 0.52 & \pm & 0.028 \\ 0.06 & \pm & 0.03 \\ 11.0 & \pm & 0.3 \\ 0.045 & \pm & 0.014 \\ 3.0 & \pm & 0.20 \\ 0.12 & \pm & 0.03\end{array}$

Units

$\mathrm{pCi} / \mathrm{m}^{3}$

$\mathrm{PCi} / \mathrm{L}$

$\mathrm{pCi} / \mathrm{g}$ (wet) $\mathrm{pCi} / \mathrm{g}$ (wet) $\mathrm{pCi} / \mathrm{g}$ (wet) $\mathrm{pCi} / \mathrm{g}$ (wet) $\mathrm{pCi} / \mathrm{g}(\mathrm{dry})$ $\mathrm{pCi} / \mathrm{g}(\mathrm{dry})$
Reference

(b)

Table A.5

Table A.15

Table A.22

Table A.24

Table A.25

Table A.26

Table A.28

Table A.38

(a) Results \pm two sigma counting error. (b) See Pricé 1985.

program at Hanford would greatly expand the area covered, at a minimal cost if based on existing commercial honeybee keepers and the judicial placement of mini-hives. 


\subsection{REFERENCES}

Bromenshenk, J. J., S. R. Carlson, J. C. Simpson, and J. M. Thomas. 1985. "Pollution Monitoring of Puget Sound with Honey Bees." Science 227:632-634.

Hakonson, T. E., and K. V. Bostick. 1976. "The Availability of Environmental Radioactivity to Honey Bee Colonies at Los Alamos." $J$. Environ. Qual. 5:307-310.

Kirkham, M. B., and J. C. Corey. 1977. "Pollen as Indicator of Radionuclide Pollution." $J$. of Nuclear Agriculture and Biology 6:71-74.

Price, K. R. 1985. Environmental Monitoring at Hanford for 1985. PNL-5817, Pacific Northwest Laboratory, Richland, Washington.

U.S. Department of Health, Education and Welfare. 1967. "Radioassay Procedures for Environmental Samples." National Center for Devices and Radiological Health, Rockville, Maryland.

Visscher, P. K., and T. D. Seeley. 1982. "Foraging Strategy of Honeybee Colonies in a Temperate Deciduous Forest." Ecology 63:1790-1801. 
PNL -7348

\section{DISTRIBUTION}

UC-603

No. of

Copies

OFFSITE

12 DOE/Office of Scientific and Technical Information

10 J. J. Bromenshenk Zoology Department University of Montana

Missoula, MT 59812

C. Callahan

U.S. Environmental Protection Agency

Corvall is Env. Res. Labs. $200 \mathrm{SW} 35$ th St.

Corvallis, OR 97333

5 J. L. Gudatis

Zoology Department

University of Montana

Missoula, MT 59812

5 0. D. Markham

U.S. Department of Energy

RESL Lab. Bld. CF 690

MS 4149

Scoville, ID 83415
No. of

Copies

ONSITE

DOE Richland Operations Office

M. M. Wall

36 Pacific Northwest Laboratory

L. L. Cadwell

L. E. Eberhardt

R. M. Ecker

J. W. Falco

J. M. Hales

P. C. Hays

W. T. Pennell

L. E. Rogers

M. A. Simmons (15)

R. L. Skaggs

M. E. Thiede

J. M. Thomas (5)

Publishing Coordination Technical Report Files 


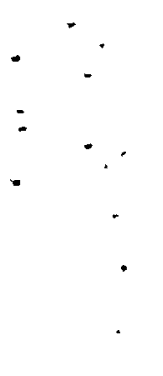

